\title{
Preface Vol 59(2)
}

This issue of the Irish Journal of Agricultural and Food Research is devoted to some of the plenary papers from the proceedings of the $27^{\text {th }}$ European Grassland Federation General Meeting, entitled 'Sustainable Milk and Meat Production from Grasslands'. The conference was organised by Teagasc and held in Cork, Ireland from $17^{\text {th }}$ to $21^{\text {st }}$ June 2018 . The conference had six session themes: 1. Resilient plants for grass based ruminant production systems, adapting grassland systems to the dynamics of climate and resource availability; 2. Appropriate livestock for grasslands, key characteristics of animals adapted to and suitable for grasslands; 3. Environmental influences on grassland systems - consequences of climate change, mitigation strategies, and impacts on ecosystems; 4 . Social and economic impacts of grass based ruminant production; 5 . Big data and smart technologies in grassland; and 6. Knowledge transfer to stakeholders.

All of the papers in this issue have been subjected to peer review and the usual editing process, and therefore may differ slightly from the plenary paper presented at the conference. 